\title{
Radon measurements in well and spring water of the Tuzla area, Bosnia and Herzegovina
}

\author{
Amela Kasić, Amira Kasumović, Feriz Adrović, and Muhamed Hodžić \\ Department of Physics, Faculty of Natural Sciences and Mathematics, University of Tuzla, Tuzla, \\ Bosnia and Herzegovina
}

[Received in February 2016; CrossChecked in February 2016; Accepted in November 2016]

\begin{abstract}
Investigations of natural radioactivity in water, air, and soil are conducted frequently and routinely. Exposure to high concentrations of natural radioactive radon gas can cause irradiation of respiratory organs, which can lead to lung cancer. This paper presents measurements of radon activity concentrations in dug wells and natural springs of the Tuzla area (Bosnia and Herzegovina), which ranged from 214 to $3702 \mathrm{mBq} \mathrm{L}-1$. Our results have shown that the radon activity concentration did not exceed the EU reference level for radon in drinking water $\left(100 \mathrm{~Bq} \mathrm{~L}^{-1}\right)$.
\end{abstract}

KEY WORDS: annual effective dose; drinking water; natural radon radiation; $p H$ value; radon activity concentration; temperature

Groundwater is favoured as a source of drinking water in many countries. It is often thought to be cleaner or easier to treat compared to surface water and as a result many wells have been either dug or drilled (1). Natural radioactivity in drinking water causes internal human exposure caused by the decay of radionuclides taken into the body through ingestion and/or inhalation indirectly when they are incorporated into the human food chain (2). Groundwater that runs through rocks also contains considerable amounts of dissolved radioactive isotopes, especially radon ( ${ }^{222} \mathrm{Rn}$ in particular) (3). Radon is the only naturally produced radioactive gas. It originates from the breakdown of uranium in soil, rock, and water. ${ }^{222} \mathrm{Rn}$ is an odourless, radioactive noble gas that originates from the decay of radium $\left({ }^{226} \mathrm{Ra}\right)$ and has a half-life of 3.8 days. Both radon and radium are part of the uranium $\left({ }^{238} \mathrm{U}\right)$ decay series. Together with the thorium $\left({ }^{232} \mathrm{Th}\right)$, actinium $\left({ }^{235} \mathrm{U}\right)$ and potassium $\left({ }^{40} \mathrm{~K}\right)$ decay series, it forms the natural decay series (4). Households that rely on water from bedrock wells are at higher risk due to elevated radon levels in the air. Radon gas dissolved in water can be released into indoor air through normal household activities such as showering, dishwashing, and laundry.

Radon circulates by two basic processes, diffusion, and forced flow. Diffusion occurs inevitably, even though its extent may be limited; therefore, diffusive migration sets a lower limit on the transport of radon. Forced flow depends on pressure gradients, which may or may not be present in a given situation. An important property of radon is its

Correspondence to: Amela Kasić, Department of Physics, Faculty of Natural Sciences and Mathematics, University of Tuzla, Tuzla, Bosnia and Herzegovina, e-mail: amela.dedic@untz.ba solubility in water; therefore it can be transported across larger distances through soil (5).

An elevated level of radon ingested through water is believed to lead to cancer, primarily of the stomach. The dominant health concern with radon, however, is the lung cancer risk created when radon gas escapes water and is inhaled (5). Ingested radon diffuses into the tissues of the stomach and small intestine. From there it enters the bloodstream and is carried throughout the body. The majority of ingested radon is thought to be exhaled when the blood flow carries it to the lungs. Based on a National Academy of Science Report, the Environmental Protection Agency (EPA) estimates that radon in drinking water causes about 168 cancer deaths per year: $89 \%$ from lung cancer and $11 \%$ from stomach cancer (6).

The Environmental Protection Agency has proposed 11.1 $\mathrm{Bq} \mathrm{L}^{-1}$ as the maximum contamination level (MCL) for radon in drinking water (7). In 2013, the European Union adopted Directive EC2013/51/EURATOM laying down requirements for protecting the health of the general public with regard to radioactive substances in water intended for human consumption (8). According to this Directive, Member States may set a level for radon that must not be exceeded, having in mind that the level set can exceed $100 \mathrm{~Bq} \mathrm{~L}^{-1}$ but not $1000 \mathrm{~Bq} \mathrm{~L}^{-1}$. Bosnia and Herzegovina currently does not have any regulations concerning the radon level in drinking water.

An important parameter of water is relative acidity or alkalinity, which is determined by measuring the $\mathrm{pH}$ value. The $\mathrm{pH}$ value of water is affected by different chemical reactions with different minerals of ground and rocks, but also with the atmosphere. Radium, the immediate parent of radon is readily soluble in low $\mathrm{pH}$ water. Also $\mathrm{pH}$ is one of 
the most important parameters influencing uranium content and its mobility. Low $\mathrm{pH}$ value is the most important water parameter linked to high radium concentration (9). The temperature of the water is also a very important parameter because it affects the development dynamics of many physical, chemical and biochemical processes. In general, increasing the temperature of water also increases the unfolding speed of certain chemical and biochemical reactions and decreases the solubility of oxygen and other gases. An increasing water temperature also decreases the solubility of radon in water (10).

Monitoring of natural radioactivity in drinking water is important in exposure assessments of to radiation by water consumption. The presence of radionuclides in drinking water can cause health hazards to humans as a result of internal radiation exposure from direct ingestion and absorption in human tissues. The aim of this paper was to investigate the ${ }^{222} \mathrm{Rn}$ concentrations in water samples collected from selected wells and springs and study the relationship between the radon concentration and temperature and $\mathrm{pH}$ values. This study also presents the estimated annual effective radon ingestion dose. The measurements presented herein are the first of its kind done according to the AlphaGUARD method in the wider region of Tuzla, Bosnia and Herzegovina (Figure 1).

\section{MATERIALS AND METHODS}

\section{Study area}

The City of Tuzla is located in the Jala basin, in northeast Bosnia. Dug wells and springs are very widespread here. Most dug wells can be found in private yards in Tuzla's suburban areas mostly at elevations greater than that of the central city area. The people inhabiting the area have grown accustomed to using water from wells on a daily basis for different purposes and even for drinking. The groundwater is drawn by a pump or using containers such as buckets.

In the areas investigated here, the depth of the dug wells ranged from 6 to $18 \mathrm{~m}$. In areas without dug wells, water samples were taken from natural springs, which are publicly available in the Tuzla area. Water samples for this research were taken from more "popular" water springs often used for drinking instead of the water from the city water supply system. The samples were collected at 13 sites with dug wells and 6 sites with natural springs (Figure 1); in mineral springs: Tuzlanski Kiseljak, Miladije Voda 1, Petrak, Slavinovići, Mosnik, and Miladije Voda 2; and dug wells: Solina 1, Solina 2, Solina 3, Brđani, Dokanj, Breške, Svojtina, Avdibašići, Hidani, Simin Han, Mandići, Čaklovići, and Dolovi.

High radon concentrations sometimes also occur in association with pegmatites, as well as gneisses and vulcanites rich in quartz and feldspar. The radon concentration in groundwater from bedrock is low in areas where uranium concentrations in the rocks are low (diorite, gabbro and basic vulcanites, limestone, sandstone, and shale) (5). The area researched mainly comprised tertiary originated sediment formations, predominantly limestone and sand, with a presence of lignite and coal deposits.

The natural spring water contained various minerals, such as salts and sulphur compounds, or calcium and magnesium. Minerals dissolve in water as they move through underground rocks. Natural springs such as Miladije Voda 1, Petrak, Slavinovići, and Miladije Voda 2 contained sulphur, while Tuzlanski Kiseljak contained a

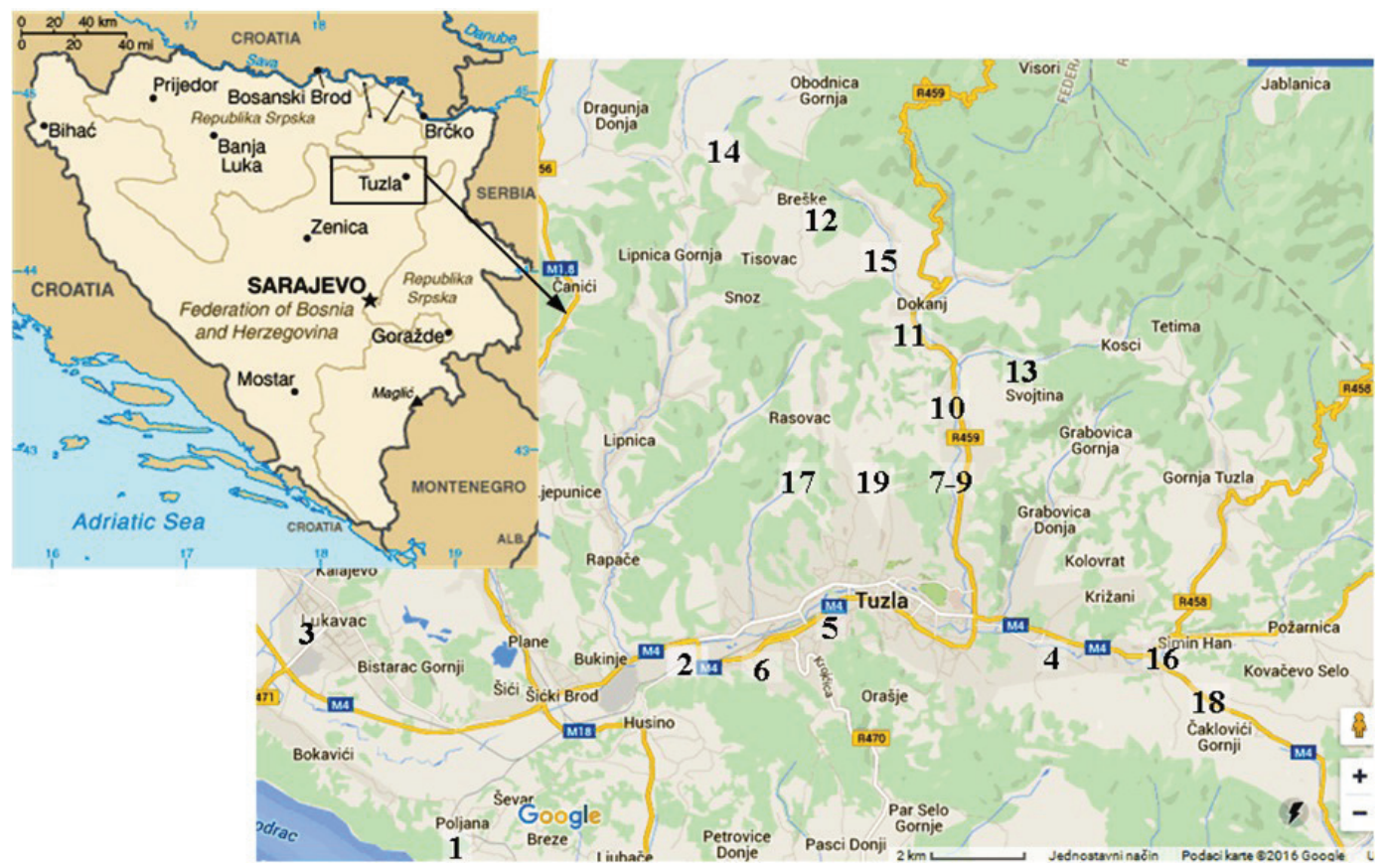

Figure 1 A map of the sampling locations 
large amount of magnesium. The natural spring water from Mosnik did not contain either sulphur or magnesium.

\section{Sampling}

The main precondition for achieving precision in radon activity concentration measurements in water is appropriate sampling. In particular, radon losses on the way between sampling and the measurement have to be minimized. During the measurements, the method of direct transfer of samples was used. For the direct transfer of samples, plastic syringes with maximum volumes of $100 \mathrm{~mL}$ were used. Further, the sample was injected directly from the syringe into the top opening of the degassed vessels. We also took care that the time between the sampling and measurement be as short as possible.

\section{Experimental design}

For measurements of the radon activity concentration in water, the AquaKIT measuring system in combination with the AlphaGUARD PQ2000PRO and AlphaPUMP electronic pumping unit (Genitron Instruments, Germany) was used. Measurements were performed by AlphaGUARD, which in addition to continuous measurements of radon concentration in air and water, can also measure basic meteorological parameters such as temperature, barometric pressure, and humidity range. The measuring range of this device for radon activity concentration is from 2 to $2 \times 10^{6} \mathrm{~Bq} \mathrm{~m}^{-3}$, while temperature measurements can range from $-10{ }^{\circ} \mathrm{C}$ to $50{ }^{\circ} \mathrm{C}$. AlphaGUARD's radon detector is based on a design-optimized pulse ionization chamber. The cylinder ionization chamber of the AlphaGUARD has an active volume of $0.56 \mathrm{~L}$, whereas its metallic interior has a potential of $+750 \mathrm{~V}$ when the instrument is turned on.

The AlphaGUARD was placed in diffusion mode with changes in measurement interval at 10 min. Radon penetrates into the inside of the appliance-ionisation chamber through a glass fibre filter, where $\alpha$-particles resulting from radioactive decay ionize the air contained within. The electrical pulses generated in the chamber correspond to the number of atoms of decaying radon. The measurement results are ultimately visible on the display $(11,12)$.

The AlphaPUMP is a battery operated electronically powered manual pumping unit for gases. It can be gradually adjusted from 0.03 to $1 \mathrm{~L}$ per minute. An internal aqua-stop filter prevents liquid material from entering the system (13).

The AquaKIT is a measuring system for directly measuring the concentration of radon gas in water. AquaKIT is used for all waters, including waste waters and highly salted waters. The glass vessels of th AquaKIT provide a hermetically enclosed volume of radon ejected from the water sample, as well as enable a quick exchange of samples, which prevents incorrect measurements resulting from leaks. The sample is injected directly from the syringe into the upper opening of the degassed vessels. In a closed circulation, radon gas is ejected from the water sample with the help of the AlphaPUMP. With the AlphaGUARD PQ2000PRO, whose ionization chamber is also part of the gas cycle, the radon concentration in the system is determined and stored.

Table 1 Geographic coordinates of the sampling locations

\begin{tabular}{lccccc}
\hline No. & Locality & Type of source & Latitude (N) & Longitude (E) & Elevation (m) \\
\hline 1 & Tuzlanski Kiseljak & mineral spring & $44^{\circ} 31^{\prime} 18^{\prime \prime}$ & $18^{\circ} 33^{\prime} 15^{\prime \prime}$ & 198 \\
\hline 2 & Miladije Voda 1 & mineral spring & $44^{\circ} 31^{\prime} 30^{\prime \prime}$ & $18^{\circ} 31^{\prime} 00^{\prime \prime}$ & 230 \\
\hline 3 & Petrak & mineral spring & $44^{\circ} 32^{\prime} 48^{\prime \prime}$ & $18^{\circ} 31^{\prime} 23^{\prime \prime}$ & 194 \\
\hline 4 & Slavinovići & mineral spring & $44^{\circ} 31^{\prime} 46^{\prime \prime}$ & $18^{\circ} 43^{\prime} 37^{\prime \prime}$ & 260 \\
\hline 5 & Mosnik & mineral spring & $44^{\circ} 32^{\prime} 01^{\prime \prime}$ & $18^{\circ} 40^{\prime} 20^{\prime \prime}$ & 272 \\
\hline 6 & Miladije Voda 2 & mineral spring & $44^{\circ} 31^{\prime} 30^{\prime \prime}$ & $18^{\circ} 31^{\prime} 00^{\prime \prime}$ & 230 \\
\hline 7 & Solina 1 & dug well & $44^{\circ} 34^{\prime} 15^{\prime \prime}$ & $18^{\circ} 42^{\prime} 01^{\prime \prime}$ & 299 \\
\hline 8 & Solina 2 & dug well & $44^{\circ} 34^{\prime} 15^{\prime \prime}$ & $18^{\circ} 41^{\prime} 59^{\prime}$ & 299 \\
\hline 9 & Solina 3 & dug well & $44^{\circ} 34^{\prime} 14^{\prime \prime}$ & $18^{\circ} 41^{\prime} 59^{\prime \prime}$ & 297 \\
\hline 10 & Brđani & dug well & $44^{\circ} 34^{\prime} 19^{\prime \prime}$ & $18^{\circ} 41^{\prime} 47^{\prime \prime}$ & 289 \\
\hline 11 & Dokanj & dug well & $44^{\circ} 35^{\prime} 40^{\prime \prime}$ & $18^{\circ} 41^{\prime} 04^{\prime \prime}$ & 337 \\
\hline 13 & Breške & dug well & $44^{\circ} 38^{\prime} 08^{\prime \prime}$ & $18^{\circ} 38^{\prime} 41^{\prime \prime}$ & 340 \\
\hline 14 & Svojtina & dug well & $44^{\circ} 33^{\prime} 47^{\prime \prime}$ & $18^{\circ} 42^{\prime} 14^{\prime \prime}$ & 312 \\
\hline 15 & Avdibašići & dug well & $44^{\circ} 35^{\prime} 04^{\prime \prime}$ & $18^{\circ} 44^{\prime} 32^{\prime \prime}$ & 414 \\
\hline 16 & Hidani & dug well & $44^{\circ} 35^{\prime} 08^{\prime \prime}$ & $18^{\circ} 43^{\prime} 49^{\prime \prime}$ & 373 \\
\hline 17 & Simin Han & dug well & $44^{\circ} 32^{\prime} 46^{\prime \prime}$ & $18^{\circ} 43^{\prime} 38^{\prime \prime}$ & 280 \\
\hline 19 & Mandići & dug well & $44^{\circ} 33^{\prime} 30^{\prime \prime}$ & $18^{\circ} 40^{\prime} 14^{\prime \prime}$ & 277 \\
\hline
\end{tabular}


For the determination of radon concentrations in the water samples, the following equation was used:

$$
C_{\text {water }}=\frac{C_{\text {air }} \times\left(\frac{V_{\text {System }}-V_{\text {Sample }}}{V_{\text {Sample }}}+k_{222 R n}\right)-C_{0}}{1000}
$$

where: $C_{\text {water }}$ is the radon concentration in water $\left(\mathrm{Bq} \mathrm{L}^{-1}\right)$; $C_{\text {air }}$ is the radon concentration in air after expelling the radon $\left(\mathrm{Bq} \mathrm{m}^{-3}\right) ; C_{0}$ is the radon concentration in the measuring equipment before sampling $\left(\mathrm{Bq} \mathrm{m} \mathrm{m}^{-3}\right) ; V_{\text {system }}$ is the interior volume of the measurement equipment $(1.122 \mathrm{~mL}) ; V_{\text {sample }}$ is the volume of the water sample $(\mathrm{mL}) ; \mathrm{k}_{222}{ }_{\mathrm{Rn}}$ is the radon diffusion coefficient (14).

Depending on the temperature diffusion coefficient, radon was calculated from the following equation:

$$
\mathrm{k}_{222}{ }_{\mathrm{Rn}}=0.106+0.405 e^{-0.052 t}
$$

where: $\mathrm{k}_{222}$ is the diffusion coefficient of radon and $t$ is water temperature $\left({ }^{\circ} \mathrm{C}\right)(15)$.

Based on the results of the measurements, the annual effective ingestion dose of radon was calculated using:

$$
H=C_{\text {water }} \cdot D \cdot G \cdot T
$$

where: $H$ is the annual effective ingestion dose for radon $\left(\mu \mathrm{Sv} \mathrm{y}^{-1}\right) ; C_{\text {water }}$ is the radon activity concentration in water $\left(\mathrm{mBq} \mathrm{L}^{-1}\right) ; D$ is the ingesting dose conversion factor for radon $\left(3.5 \mathrm{nSv} \mathrm{Bq}^{-1}\right) ; G$ is the water consumption per day; $T$ is the duration of consumption (16).

In order to calculate the annual effective dose for radon obtained by ingesting water from the investigated water samples, we used an annual intake of water of $2 \mathrm{~L}$ per day, which corresponds to the consumption of population over 17 years of age (17).

\section{RESULTS AND DISCUSSION}

Table 1 shows the geographic coordinates of the sampling locations, while Table 2 shows the temperature values of the investigated water samples and the calculated diffusion coefficients. The $\mathrm{pH}$ values and radon activity concentration in air before the start of measurement and after expelling the radon from the water samples are also shown in Table 2 . The radon activity concentration in the air after expulsion from the water samples ranged within $38-350 \mathrm{~Bq} \mathrm{~m}^{-3}$ and $22-155 \mathrm{~Bq} \mathrm{~m}^{-3}$ for dug wells and natural springs, respectively.

The radon activity concentration in the water ranged 214-3702 $\mathrm{mBq} \mathrm{L}^{-1}$ in general, and for dug wells alone $385-$ $3702 \mathrm{mBq} \mathrm{L} \mathrm{L}^{-1}$, with the highest concentration found at locality Solina 3 (No. 9, Table 2, Figure 2) and the lowest at Dolovi (No. 19, Table 2, Figure 2). These locations are not geographically far apart, but they are at different elevations: Dolovi are approximately $100 \mathrm{~m}$ higher than Solina 3. Also, the depth of the well at Solina 3 was much greater than at Dolovi. Furthermore, location Solina 3 is accommodated in a plain area where soils with ruinous limestone prevail and may in some places even be clayey.

The activity concentration of radon in water samples from natural springs was in the range from 214 to $1607 \mathrm{mBq} \mathrm{L}^{-1}$. The highest value was determined at locality Mosnik (No. 5, Table 2, Figure 2) and the lowest at Miladije Voda 2 (No. 6, Table 2, Figure 2). As obvious, Mosnik had a much higher activity concentration in comparison to other mineral springs. Mosnik is located near an urban part of Tuzla, at a higher elevation than the other investigated natural springs. Its water comes from bedrock built mainly of quartz sand.

The radon activity concentrations for dug wells obtained in this study are much lower than, for instance, those

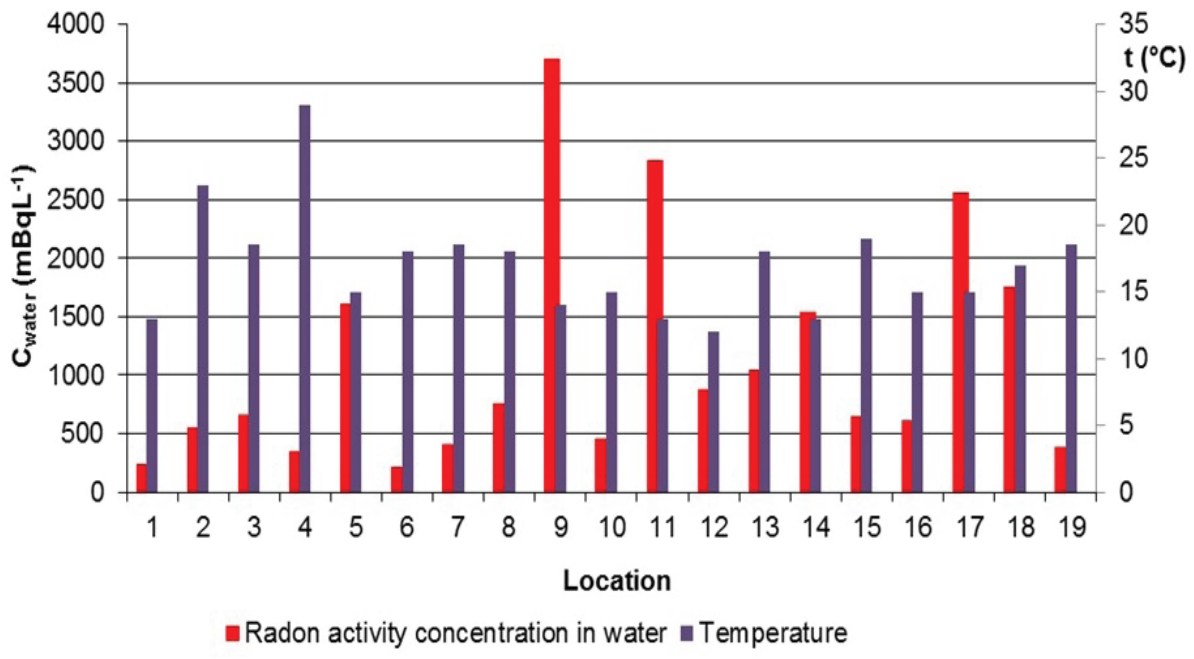

Figure 2 The radon activity concentration $\left(C_{\text {wate }}\right)$ and the temperature $(t)$ of the investigated water samples 
Table 2 The values of the radon activity concentration in the air before the start of measurement $\left(C_{0}\right)$ and after expelling radon from the water samples $\left(C_{a i}\right)$, $p H$ value, temperature, diffusion coefficient, and radon activity concentration

\begin{tabular}{|c|c|c|c|c|c|c|c|c|c|}
\hline No. & Locality & Type of source & $\begin{array}{c}\text { Depth of } \\
\text { dug well } \\
\text { (m) }\end{array}$ & $\begin{array}{c}\mathbf{t} \\
\left({ }^{\circ} \mathrm{C}\right)\end{array}$ & pH & $\mathbf{k}_{222 \mathrm{Rn}}$ & $\begin{array}{c}\mathrm{C}_{0} \\
\left(\mathrm{~Bq} \mathrm{~m}^{-3}\right)\end{array}$ & $\begin{array}{c}\mathrm{C}_{\mathrm{air}} \\
\left(\mathrm{Bq} \mathrm{\textrm {m } ^ { - 3 }}\right)\end{array}$ & $\begin{array}{c}\mathrm{C}_{\text {water }} \\
\left(\mathrm{mBq} \mathbf{L}^{-1}\right)\end{array}$ \\
\hline 1 & Tuzlanski Kiseljak & mineral spring & - & 13 & 6.3 & 0.31 & 14 & 24 & 239 \\
\hline 2 & Miladije Voda 1 & mineral spring & - & 23 & 8.5 & 0.23 & 20 & 55 & 555 \\
\hline 3 & Petrak & mineral spring & - & 18.5 & 8.5 & 0.26 & 11 & 64 & 660 \\
\hline 4 & Slavinovići & mineral spring & - & 29 & 8.3 & 0.19 & 14 & 35 & 350 \\
\hline 5 & Mosnik & mineral spring & - & 15 & 7.3 & 0.29 & 22 & 155 & 1607 \\
\hline 6 & Miladije Voda 2 & mineral spring & - & 18 & 6.3 & 0.26 & 17 & 22 & 214 \\
\hline 7 & Solina 1 & dug well & 13 & 18.5 & 7.2 & 0.26 & 19 & 41 & 411 \\
\hline 8 & Solina 2 & dug well & 12 & 18 & 7.3 & 0.26 & 10 & 73 & 755 \\
\hline 9 & Solina 3 & dug well & 18 & 14 & 7.3 & 0.3 & 20 & 350 & 3702 \\
\hline 10 & Brđani & dug well & 9 & 15 & 7.6 & 0.29 & 10 & 45 & 463 \\
\hline 11 & Dokanj & dug well & 16 & 13 & 7.5 & 0.31 & 27 & 272 & 2837 \\
\hline 12 & Breške & dug well & 10 & 12 & 7.1 & 0.32 & 27 & 86 & 880 \\
\hline 13 & Svojtina & dug well & 12 & 18 & 7.1 & 0.26 & 27 & 102 & 1042 \\
\hline 14 & Avdibašići & dug well & 11 & 13 & 7 & 0.31 & 20 & 148 & 1538 \\
\hline 15 & Hidani & dug well & 9 & 19 & 7.6 & 0.26 & 24 & 65 & 657 \\
\hline 16 & Simin Han & dug well & 10 & 15 & 7.2 & 0.29 & 14 & 60 & 617 \\
\hline 17 & Mandići & dug well & 14 & 15 & 7.4 & 0.29 & 12 & 245 & 2563 \\
\hline 18 & Čaklovići & dug well & 11 & 17 & 7.3 & 0.27 & 15 & 169 & 1758 \\
\hline 19 & Dolovi & dug well & 6 & 18.5 & 7.2 & 0.26 & 13 & 38 & 385 \\
\hline \multicolumn{3}{|c|}{ mineral spring range } & & $13-29$ & $6.3-8.5$ & $0.19-0.31$ & $11-22$ & $22-155$ & $214-1607$ \\
\hline \multicolumn{3}{|c|}{ dug well range } & $6-18$ & $12-19$ & $7-7.6$ & $0.26-0.32$ & $10-27$ & $38-350$ & $385-3702$ \\
\hline \multicolumn{3}{|c|}{ mineral spring } & & $19.4 \pm 5.8$ & $7.4 \pm 1.1$ & $0.26 \pm 0.04$ & $16.3 \pm 4.1$ & $59 \pm 50$ & $604 \pm 522$ \\
\hline \multicolumn{3}{|c|}{ dug well } & $11.6 \pm 3.2$ & $15.8 \pm 2.4$ & $7.3 \pm 0.2$ & $0.28 \pm 0.02$ & $18.3 \pm 6.5$ & $130 \pm 101$ & $1354 \pm 1069$ \\
\hline
\end{tabular}

observed in Croatia; 4.0-17.4 $\mathrm{Bq} \mathrm{L}^{-1}(18)$ and 4.4-17.6 Bq L-1 (19). In comparison with radon concentrations in bottled tap water from Serbia, the values were not very different (20). The highest radon activity concentration in our study is lower than any of the ${ }^{222} \mathrm{Rn}$ concentrations observed in drinking water in Bulgaria (21). Furthermore, in comparison with the EU reference level, as well as those in Russia (120 Bq L $\left.{ }^{-1}\right)$, Norway $\left(500 \mathrm{~Bq} \mathrm{~L}^{-1}\right)$, and Finland $\left(1000 \mathrm{~Bq} \mathrm{~L}^{-1}\right)$, the values obtained in this study were much lower $(22,23)$.

The lowest temperature value in the tested samples was $12{ }^{\circ} \mathrm{C}$, at Breške (No. 12, Table 2) with a diffusion coefficient of 0.32 , whereas the highest temperature in the tested samples was $29^{\circ} \mathrm{C}$, at Slavinovići (No. 4, Table 2) with a corresponding diffusion coefficient of 0.19 . Figure 2 shows the radon activity concentration in water as a function of the temperature of the investigated water samples. Contrary to expectations, no dependence between drinking water temperature and radon concentration was detected (Figure 3). Radon activity concentration and temperature had a negative weak correlation $(r=-0.43)$. The correlation coefficients between radon and temperature for dug wells and mineral springs were -0.50 and -0.28 , respectively.

The $\mathrm{pH}$ value varied from 7.0 to 7.6 for the wells, and 6.3-8.5 for the natural springs. The results in Table 2 and Figure 4 indicate that the radon activity concentration was independent from $\mathrm{pH}$ value of water. Radon activity concentration and $\mathrm{pH}$ value of water had no correlation $(\mathrm{r}=0.01)$ and very weak correlation coefficients were obtained (Figure 5). 


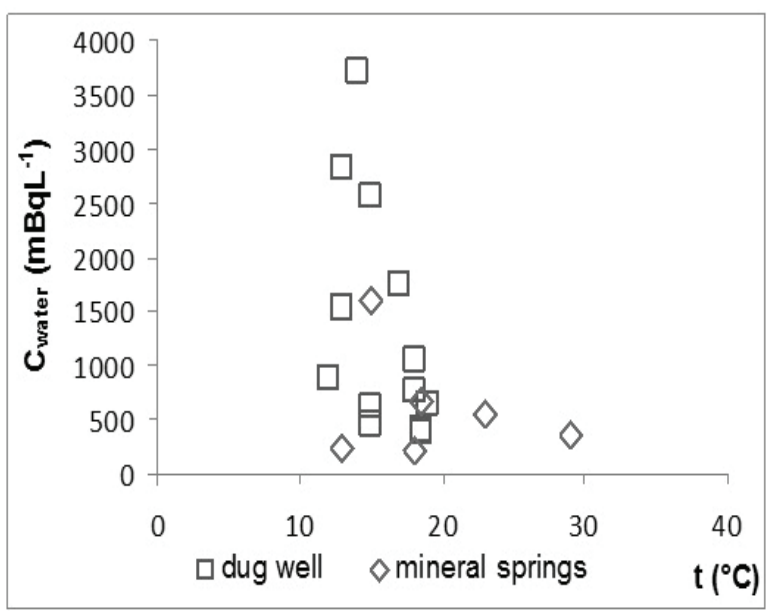

Figure 3 The radon activity concentration $\left(C_{\text {wate }}\right)$ as a function of the temperature ( $t$ ) of the water samples

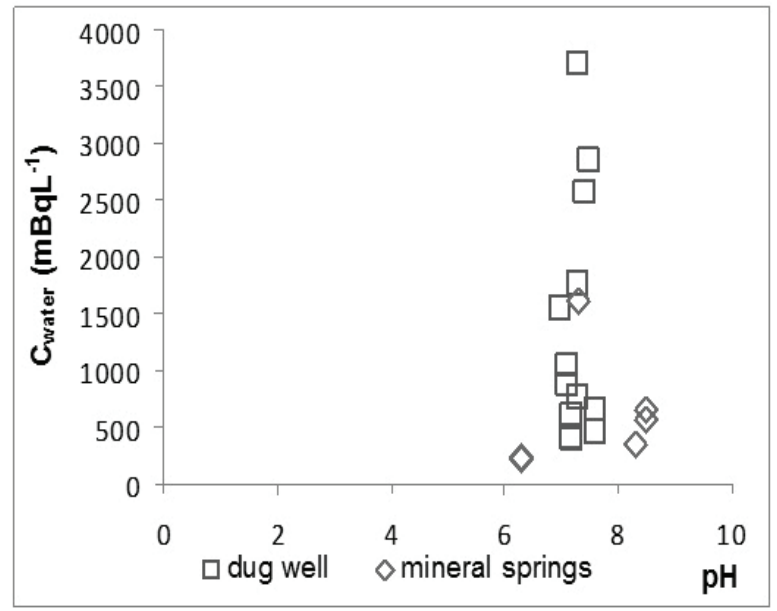

Figure 5 The radon activity concentration $\left(C_{\text {wate }}\right)$ as a function of the $\mathrm{pH}$ value of the water samples

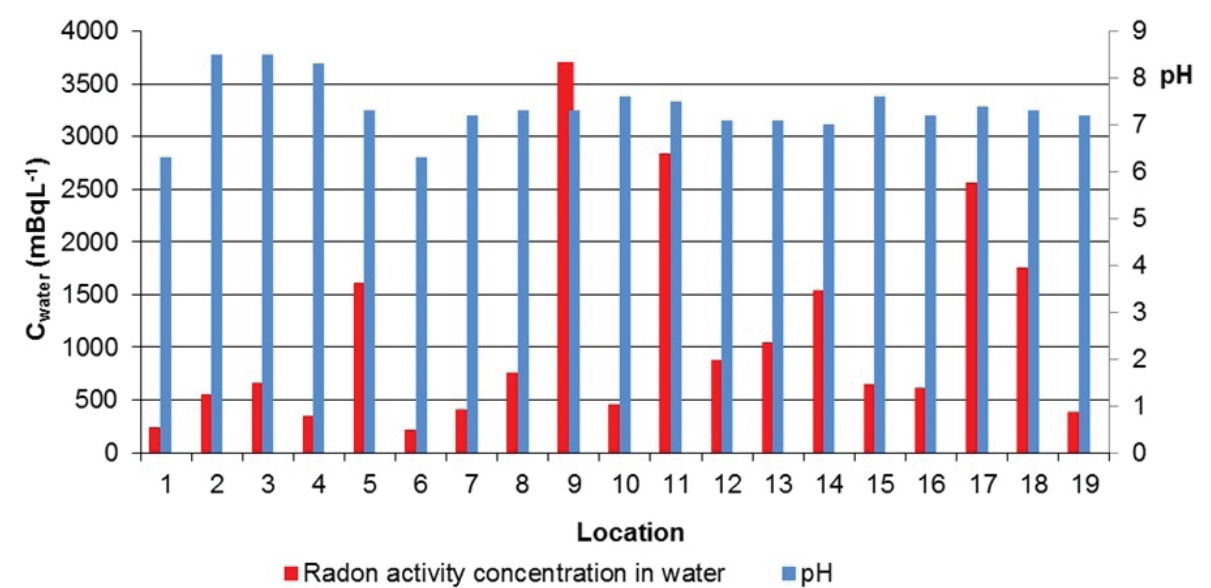

Figure 4 The radon activity concentration $\left(C_{\text {wate }}\right)$ and the $\mathrm{pH}$ value of the investigated water samples

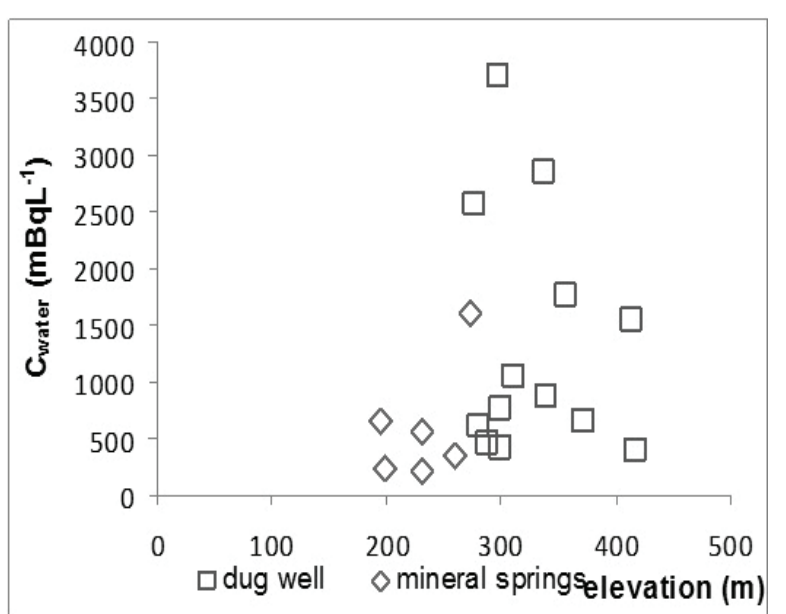

Figure 6 The radon activity concentration $\left(C_{\text {water }}\right)$ as a function of the elevation of the sampling locations

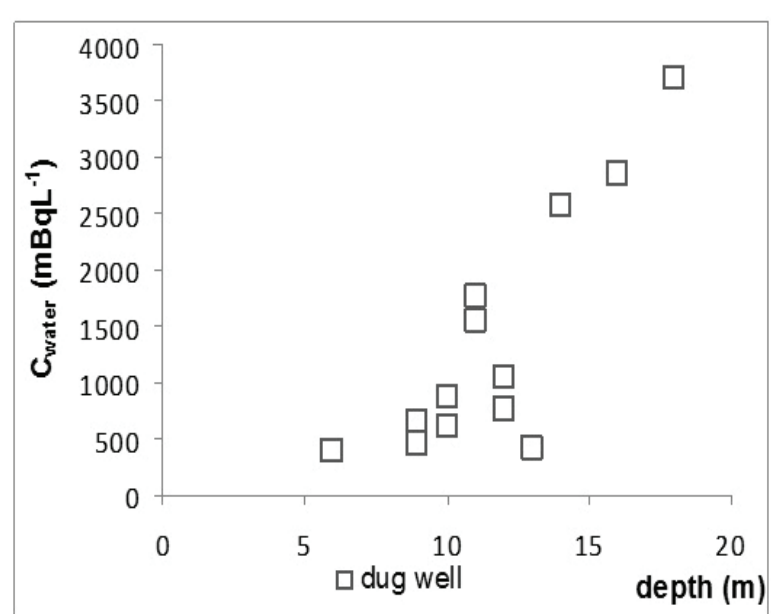

Figure 7 The radon activity concentration $\left(C_{\text {wate }}\right)$ as a function of the dug well depth 


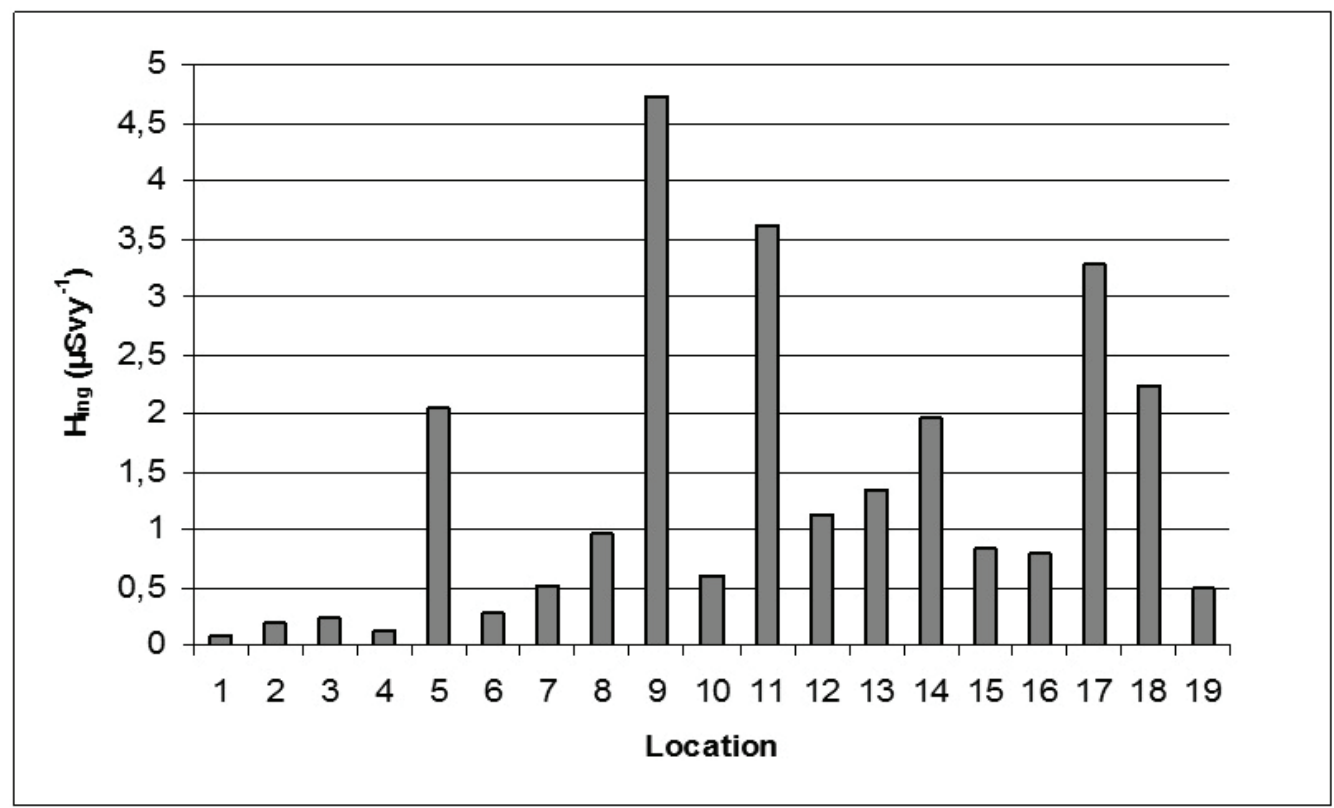

Figure 8 The annual effective ingestion dose for radon at the researched location

According to the elevation of the sampling location, a moderate negative correlation was found for mineral spring water and a very weak one for dug well water (Figure 6).

The depth of every well was measured and related to the obtained activity concentrations (Table 2). As can be seen from Figure 7, a strong positive correlation between the radon activity concentration and the depth of the dug wells was determined $(\mathrm{r}=0.84)$. The radon activity concentration for water samples increased with the depth of the dug well.

The estimated annual effective dose received by the population as a result of ingesting the water was in the range 0.08-4.72 $\mu \mathrm{Sv} \mathrm{y}^{-1}$ (Figure 8), which is within the same range as for Novi Sad City, Serbia and lower than for dug well water in Croatia $(6,18-20)$. The range does not exceed the reference level of $0.1 \mathrm{mSv} \mathrm{y}^{-1}$ recommended by the World Health Organization (WHO) (24).

\section{CONCLUSIONS}

The radon activity concentrations in Tuzla's drinking waters were below the reference level recommended by the EU $\left(100 \mathrm{~Bq} \mathrm{~L}^{-1}\right)$. The results presented in this paper have shown that the radon activity concentration did not depend on $\mathrm{pH}$ value and temperature of water, but most likely did depend on depth. What is perhaps most important in this, the annual ingestion dose for the investigated water samples was proven to be below the proposed reference level (24).

\section{REFERENCES}

1. Skeppström K, Olofsson B. Uranium and radon in groundwater. European Water 2007;17/18:51-62 [displayed
30 November 2016]. Available at http://www.ewra.net/ew/ pdf/EW_2007_17-18_05.pdf

2. Kasić A, Adrović F, Kasumović A, Hankić E. Levels of natural radioactivity in mineral and thermal waters of Bosnia and Herzegovina. Nukleonika 2015;60:503-8. doi: 10.1515/ nuka-2015-0062

3. Przylibski T, Dorda J, Kozlowska B. The occurrence of ${ }^{226}$ Ra and ${ }^{228} \mathrm{Ra}$ in groundwaters of the Polish Sudety Mountains. Nukleonika 2002;47:59-64 [displayed 30 November 2016]. Available at http://www.ichtj.waw.pl/ichtj/nukleon/back/full/ vol47_2002/v47n2p059f.pdf

4. van der Pal M. Radon Transport in Autoclaved Aerate Concrete. Eindhoven: University of Technology; 2003.

5. Durrani S, Ilić R, editors. Radon Measurements by Etched Track Detectors - Application in Radiation Protection, Earth Sciences and the Environment. Singapore: Word Scientific Publishing Company; 1997.

6. Nikolov J, Todorović N, Forkapić S, Bikit I, Mrdja D. Radon in drinking water in Novi Sad. Int J Mathem Comput Phys Electr Comput Engin 2011;5:539-42 [displayed 30 November 2016]. Available at http://waset.org/publications/6033/radonin-drinking-water-in-novi-sad

7. United States Environmental Protection Agency (US EPA). Radon Measurement Proficiency (RMP) Program Handbook. EPA 520/1-91-006. Washington (DC): Office of Radiation Programs, 1991.

8. European Commission. Council Directive 2013/51/ EURATOM of 22 October 2013. Laying down requirements for the protection of the health of the general public with regard to radioactive substances in water intended for human consumption. Off J Eur Commun 2013:L296:12-21.

9. Sharma N, Sharma R. Survey of radon concentration in drinking water samples of Hoshiarpur and Ropar districts of Punjab, India. Adv Appl Sci Res 2013;4:226-31.

10. Cothern C, Smith JE. Environmental Radon. New York (NY): Plenum Press; 1987. 
11. AlphaGuard PQ 2000/MC50 Multiparameter Radon Monitor. Characterisation of its physical properties under normal climatic and severe environmental conditions. User Manual. Germany: Genitron Instruments; 2-6, 1998.

12. AlphaGUARD. Portable Radon Monitor. User manual. Germany: Genitron Instruments; 1998.

13. AlphaPUMP. Technical Description. User manual. Germany: Genitron Instruments; 2001.

14. AquaKIT. Accessory for radon in water measurement in combination with the radon monitor AlphaGUARD. User manual. Germany:Genitron Instruments;1997.

15. Machaj B, Bartak J. Fast measurement of radon concentration in water with Lucas cell. Nukleonika 2004;49:29-31. [displayed 30 November 2016]. Available at http://www.ichtj. waw.pl/ichtj/nukleon/back/full/vol49_2004/v49n1p029f.pdf

16. Kasić A, Hankić E, Kasumović A, Adrović F. Levels of radon activity concentration in thermal waters of Bosnia and Herzegovina. J Mater Sci Engin 2013;B3:539-44.

17. International Commission on Radiological Protection (ICRP). 1990 Recommendations of the International Commission on Radiological Protection. ICRP Publication 60. Oxford: Pergamon Press; 1990.

18. Radolić V, Šimatović V, Miklavčić I. Radon u vodi gradskih vodovoda u naseljima Osječko-baranjske županije [Radon in public waterworks of the cities of Osijek-Baranja County, in Croatian]. In: Barišić D, Grahek Ž, Krajcar Bronić I, Miljanić S, editors. Proceedings of the Seventh Symposium of the Croatian Radiation Protection Association; 29-31 May 2008; Opatija, Croatia 2008. Zagreb: Croatian Radiation Protection Association; 2008. p. 300-6.
19. Radolić V, Šarić I, Miklavčić I. Radon u vodi gradskih vodovoda u naseljima Požeško-slavonske županije [Radon in public waterworks of the cities of Požega-Slavonia County, in Croatian]. In: Barišić D, Grahek Ž, Krajcar Bronić I, Miljanić S, editors. Proceedings of the Seventh Symposium of the Croatian Radiation Protection Association; 29-31 May 2008; Opatija, Croatia 2008. Zagreb: Croatian Radiation Protection Association; 2008. p. 294-9.

20. Todorovic N, Nikolov J, Forkapić S, Bikit I, Mrdja D, Krmar M, Veskovic M. Public exposure to radon in drinking water in Serbia. Appl Radiat Isot 2012;70:543-9. doi: 10.1016/j. apradiso.2011.11.045

21. Totzeva R. Kotova R. Radon and radium-226 content in some Bulgarian drinking waters. In: Morell M, Popovska C, Morell O, Stojov V, editors. Proceedings of the $4^{\text {th }}$ Conference on Water Observation and Information System for Decision Support; 25-29 May 2010; Ohrid, Republic of Macedonia. Skopje: Faculty of Civil Engineering; 2010.

22. Jobbágy V, Altzitzoglou T, Malo P, Tanner V, Hult M. A brief overview on radon measurements in drinking water. J Environ Radioact 2016 [displayed 30 November 2016]. Available at http://www.sciencedirect.com/science/article/pii/ S0265931X16304556

23. Åkerblom G. Radon Legislation and Natural Guidelines. Swedish Radiation Protection Institute: Department of Environmental Monitoring and Dosimetry, 1999 [displayed 30 November 2016]. Available at http://www.elradon.com/ web/wp-content/uploads/2011/08/Radon-Legislation-andNational-Guidelines.pdf

24. World Health Organisation (WHO). Guidelines for drinking water quality. $3^{\text {rd }}$ ed. Geneva; WHO; 2004.

\section{Mjerenje koncentracije radona u bunarskoj i izvorskoj vodi na području Tuzle, Bosna i Hercegovina}

Istraživanja o koncentraciji aktivnosti radona u vodi, zraku i tlu dobro su znana. Izlaganje visokim razinama koncentracije aktivnosti radona uzrokuje ozračivanje dišnih organa, što može dovesti do raka pluća. U ovom su radu predstavljeni rezultati istraživanja o koncentraciji aktivnosti radona $u$ vodi za piće uzorkovanoj iz bunara i prirodnih izvora na tuzlanskome području. Mjerenja su provedena radon mjernim sustavom AlphaGUARD. Razine koncentracije aktivnosti radona na istraživanim lokalitetima bile su od 214 do $3702 \mathrm{mBq} \mathrm{L}{ }^{-1}$. Dobiveni rezultati pokazali su da je koncentracija radona $\mathrm{u}$ istraživanim uzorcima bunarske $\mathrm{i}$ izvorske vode niža od $100 \mathrm{~Bq} \mathrm{~L}{ }^{-1}$, što je razina koncentracije aktivnosti radona u vodi za piće koju je predložila Europska komisija.

KLJUČNE RIJEČI: godišnja efektivna doza; voda za piće; prirodna radijacija radona; $p H$ vrijednost, koncentracija aktivnosti radona; temperatura 